ANUVA Volume 2 (3): 243-251, 2018

Copyright @2018, ISSN: 2598-3040 online

Available Online at: http://ejournal.undip.ac.id/index.php/anuva

\title{
Penguatan Karakter Kebangsaan Melalui Media Sosial pada Masyarakat Desa Nolokerto Kecamatan Kaliwungu
}

\author{
Ana Irhandayaningsih ${ }^{1 *}$

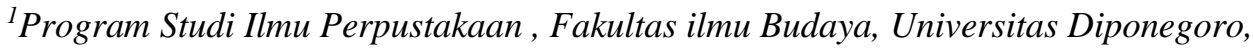 \\ Jl. Prof Soedarto,SH, Kampus Undip, Semarang Indonesia. \\ *) Korespondensi: irhandayaningsih@gmail.com
}

\begin{abstract}
The article entitled strengthening national character through social media in the nolokerto village community, kaliwungu sub-district, kendal was written with the aim of knowing the extent to which social media influences the strengthening of national character. By using a qualitative descriptive method, beginning with observations to the field, it finally gets a conclusion that shows that social media is very influential for strengthening national character. This is because most people in the village of Nolokerto use mobile phones as a means of communication, in fact they have considered social media an important necessity in its hideup. Through Facebook, Twitter, WhatsUp, Online, they communicate with their surroundings. Even more use of social media in communication compared to direct interaction. This is very influential for their daily behavior and attitudes.
\end{abstract}

Keywords: reinforcement; national character; social media

\begin{abstract}
Abstrak
Artikel yang berjudul penguatan karakter kebangsaan melalui media sosial pada masyarakat desa nolokerto kecamatan kaliwungu Kabupaten kendal ini ditulis dengan tujuan mengetahui sejauh mana media sosial berpengaruh pada penguatan karakter kebangsan. Dengan menggunakan metode deskriptif kualitatif dengan diawali dengan observasi ke lapangan akhirnya mendapatkan suatu hasil kesimpulan yang menunjukan bahwa media sosial sangat berpengaruh bagi penguatan karakter kebangsaan. Hal ini karena sebagian besar masyarakat di desa Nolokerto menggunakan handphone sebagai alat komunikasi, Bahkan mereka sudah menganggap media sosial sebagai suatu kebutuhan penting dalam hideupnya. Melalui facebook, twiter, whatsup, line, mereka melakukan komunikasi dengan sekitarnya. Bahkan lebih banyak menggunakan media sosial dalam berkomunikasi dibanding dengan interaksi langsung. Hal ini sangat berpengaruh bagi perilaku dan sikap mereka sehari-hari.
\end{abstract}

Kata kunci : penguatan; karakter kebangsaan; media sosial

\section{Pendahuluan}

Desa Nolokerto ialah salah satu dari sembilan desa yang ada di Kecamatan Kaliwungu, Kabupaten Kendal. Desa Nolokerto memiliki batas-batas sebelah utara berbatasan degan desa Nolokerto, Kecamatan Kaliwuungu, sebelah timur berbatasan dengan Desa Sumberejo, sebelah selatan berbatasan dengan Desa Protomulyo, Kaliwungu Selatan dan sebelah barat berbatasan dengan Desa Nolokerto. Secara astronomis, Desa Nolokerto terletak antara $109^{\circ} 40^{\circ}-110^{\circ} 18^{\circ}$ Bujur Timur dan $6^{\circ} 32^{\circ} 30^{\circ}-7^{\circ} 24^{\circ}$ Lintang Selatan. Luas wilayah dari Desa Nolokerto adalah $5,19 \mathrm{~km}^{2}$ yang terbagi atas tujuh dusun dan secara kelembagaan terbagi atas 7 RW dan 41 RT. Dusun yang ada di Desa Nolokerto yaitu Dusun Mijen, Dusun Kwayuhan Barat, Dusun Kwayuhan Timur, Dusun Mangir, Dusun Nolokerten dan Dusun Penjor. Tingkat pendidikan dari masyarakat Desa Nolokerto belum cukup baik, dimana hampir sebagian besar penduduk 
belum sekolah dan tamatan SD. Desa Nolokerto sendiri memiliki total 5 Taman Kanak-Kanak dan 3 Sekolah Dasar dan 1 Madrasah Ibdtidaiyah.

Kondisi topografi wilayah Desa Nolokerto terdiri dari daerah dataran rendah dengan ketinggian rata-rata 15 sampai 20 meter diatas permukaan laut. Wilayah Desa Nolokerto merupakan daerah yang berbukit-bukit yang memiliki kemiringan yang tidak terlalu landai dan curam. Jenis tanah di Wilayah Desa Nolokerto terdiri dari tanah regosol batu-batuan pasir dan intermedier dan tanah latosal yang terdiri dari batu bekuan pasir. Pemanfaatan tanah sebagian besar digunakan untuk bangunan perumahan/gedung, petanian, tanaman pangan, palawija dan sayur-sayuran, pekarangan, tempat usaha, lembaga pendidikan dan sosial kemasyarakatan.

Sebagian masyarakat di desa Nolokerto bermata pencaharian pertanian dan industri. Media sosial tidak pernah terlepas dalam kehidupan sehari-harinya, walaupun sebagaian besar di bidang pertanian tetapi masyarakat tidak pernah ketinggalan mengikuti berita lewat media sossial. Hal yang demikian sangat mempengaruhi pola perilaku dan sikap dalam kesehariannya. Kemajuan dan perkembangan teknologi membuat masyarakat sangat mudah mengakses informasi atau menyampaikan informasi melalui media sosial. Demikian juga masyarakat di desa nolokerto ini, walaupun keseharian hanya bertani akan tetapi media sosial bagi mereka tidak asing lagi. Masyarakat di sisni sangat paham apa yang namanya facebook, twiter, wa, line dan lain sebaginya. Hal ini tentu saja akan sangat mempengaruhi perilaku pada masyarakat, karena masyarakat dengan sangat mudah bisa mengakses apapun lewat handphone.

Media sosial merupakan sesuatu yang tidak asing bagi masyarakat nolokerto terutama di kalangan geneasi muda. Facebook, twiter, wa, line instragram, merupakan hal yang tidak bisa lepas dalam kehidupan sehari-harinya. Hal ini sangat terlihat dalam kesehariannya, hampir disetiap pertemuan ada handphone di tangan, bahkan mereka kebanyakan tidak mempedulikan hal sekelilingnya dan hanya focus pada handphone dengan segala aplikasinya. Segala aktivitas kesehariannya tidak pernah lepas dari gadged nya, aktivitas apapun selalu menggunakan handphone nya. Di rumah di sekolah di pasar sama teman sama keluargan tidak pernah bisa lepas dari handphone.

Banyak hal yang bisa di akses melalui handphone, hal inilah yang bisa mempengaruhi karakter atau kepribadian masyarakat terutama generasi muda. Karakter yang bisa kita amati adalah dengan handphone atau gadged di tangan mereka lebih cenderung berubah menjadi individualis. Lebih mengutamakan menggunakan gadged dari pada langsung ketemu dengan teman secara langsung. Mereka sudah memiliki group-group di wa line dan sebaginya sehingga lebih mudah ngobrol lewat medis]a sosial dari pada bertemu langsung. Hal ini juga karena di era globbalilasi sekarang masyarakat lebih berpikir secara praktis dengan beranggapan lebih mudah ngobrol lewat media sosial dari pada bertemu yang harus menyediakan waktu dan tempatkhusus. Dengan menggunakan media sosial bisa ngobrol dengan cara apapun dan tempat dimanapun.

Hal yang sudah diuraikan di atas hanya sedikit gambaran di masyarakat nolokerto di kecamatan kaliwungu. Masyarakat desa yang dulunya sangat menjunjung tinggi untuk bersosialisasi dengan tetangga dan teman yang di sekitarnya sedikit banyak sudah mulai berubah karena kemajuan teknologi. 


\section{Landasan Teori}

Karakter bersasal dari bahasa Yunani "character" dari "charassein yang berarti membuat tajam. Menurut kamus umum bahasa Indonesia, karakter diartikan sebagai tabiat, watak, sifat-sifat kejiwaan, akhlak atau budi pekerti yang membedakan seseorang dengan yang lain. Sementara dalam kamus sosiologi, karakter diartikan sebagai ciri khusus struktur dasar kepribadian seseorang (Supriyadi, 2018). Sedangkan menurut soemarno Soedarsono pengertian karakter adalah sebuah nilai yang sudah ada dalam diri sesorang yang diperoleh dari pengalaman, pendidikan, serta adanya pengaruh lingkungan yang kemudiaan mendasari sikap perilaku dan pemikiran seseorang. Dari kedua definisi diatas menunjukan bahwa karakter sebagai suatu cri khas yang dimiliki oleh seseorang yang sudah melekat dan terlihat dalam perilaku watak serta pemikiran dalam kesehariannya.

Istilah kebangsaan mengutip dari apa yang pernah dikatakan oleh Ir. Soekarno, bahwa kebangsaan adalah ciri yang melekat pada suatu bangsa yang harus bisa kita junjung tinggi sampai kapanpun. Kebangsaan Indonesia merupakan ciri yang dimiliki oleh bangsa Indonesia terutama yang berdasar pada sila-sila Pancasila. Sedangkan karakter kebangsaan bisa dimaknai sebagai suatu ciri khas yang menunjukan seseorang atau sekelompok orang memiliki karakter yang tidak bisa terlepas dari ciri khas suatu bangsa yang dimiliki oleh individu atau sekelompok orang. Indonesia sebagai bangsa yang memiliki ciri Pancasila sebagai dasar negara, mengharuskan bangsa Indonesia selalu melaksanakan dan mentaati nilai-nilai dasar Pancasila, hal ini bisa tercermin dari perilaku sehari-hari dari masyarakat tersebut.

Pengertian media sosial menurut Antony Mayfield adalah sesuatu yang memudahkan anggotanya untuk bisa berinteraksi yang berupa blog, jejaring, web, dan lain sebaginya. Hal ini menunjukan jika media sosial sebagai sarana untuk berkomunikasi dengan bebas memalui dunia maya. Sedangkan menurut Kotler dan Keller ada 3 jenis media sosial yaitu :

a. Online Communities

b. Blogs

c. Sosial networks

Online Communities yang dimaksud adalah suatu media sosial yang digunakan secara komersial atau oleh perusahaan tertentu sebagai salah satu cara dallam perdagangan atau komunikasi tawar menawar suatu produk yang ditawarkan yang kedua belah pihak saling memberikan keuntungan.

Sedangkan blogs sebagai sarana media sosial untuk menuliskan atau mengemukakan pendapat pribadi agar supaya diketahui oleh orang lain. Blogs bisa dibaca oleh siapa saja.

Jenis terakhir sosial networks adalah jenis media sosial yang paling banyak digunakan oleh semua orang. Jenis ini antara lain, whatsup, facebook, twiter, dan lain sebagainya. Jenis sosial networks ini merupaka jenis yang sangat mudah dipergunakan untuk berkomunikasi.

Media sosial yang populer dan sangat banyak digunakan di Indonesia adalah 

a. Facebook.
b. Youtube
c. Blog
d. Twitter
e. Instagram

Menurut Sanjaya (2010), media sosial dapat mempersatukan semua lapisan masyarakat, itulah bukti nyata bahwa dengan media sosial masyarakat, baik disuatu wilayah maupun secara global pun dapat dipersatukan melalui media sosial.

\section{Metode Penelitian}

Penelitian ini menggunakan metode penelitian deskriptif kualitatif yaitu penulis ingin memberikan gambaran ssecara lengkap dan menyeluruh tentang penguatan karakter kebangsaan melalui media sosial pada masayarakayt desa Nolokerto kecamatan Kaliwungu Kabupaten Kendal. Dengan melakukan observasi secara langsung dan melakukan wawancara langsung terhadap masyarakat untuk mengetahui sikap perilaku masyarakat, yang nantinya akan didapatkan karakter kebangsaan yang muncul karena media sosial.

Teknik pemilihan informan yang digunakan dalam penelitian ini adalah menggunakan teknik snowball sampling, yaitu dengan dimulai dengan jumlah kecil (satu orang) yang merupakan informan kunci, kemudian atas rekomendasi orang tersebut, informan menjadi semakin besar sampai jumlah tertentu. Informan yang dipilih oleh peneliti ialah infroman yang dapat memberikan informasi dan penjelasan tentang media sosial khusunya yang sering menggunakan media sosial sebagai sarana dalam berkomunikasi.

Sedangkan teknik pengumpulan data yang digunakan adalah dengan observasi dan wawancara semi terstruktur dan ditambah dengan dokumentasi untuk menambah kekayaan kajian penelitian sehingga mendapatkan hasil yang maksimal

\section{Hasil dan Pembahasan}

\section{a. Media Sosial}

Masyarakat di desa nolokerto kecamatan kaliwugu kabupaten Kendal, sebenarnya sudah memiliki ciri khas sebagai masyarakat yang memiliki sosialitas tinggi. Hal ini bisa dilihat keseharian mereka tidak pernah terlepas dari kepedulian terhadap lngkungan tempat tinggalnya. Di tengah kesibukan mengerjakan tugas - tugas pekerjaannya sebagai petani maupun ke industri atau pekerjaan yang lainnya, masyarakat di desa Nolokerto masih bisa meluangkan waktunya untuk membantu tetangga sekitar atau sekedar bersosialisasi dengan yang lain. Saling membantu manakala tetangga mendapat kesusahan atau memenuhi kewajiban sebagai warga masyarakat untuk mengikuti perkumpulan warga sekitar, arisan, pengajian, posyandu dan lain-lainnya. 
Seiring dengan perkembangan yang semakin maju, dengan dibarengi dengan perkembangan teknologi yang luar biasa, kehidupan masyarakat di desa Nolokerto juga sedikit banyak mengalami perubahan. Perubahan ini dilihat dari perilaku cara hidup cara berpikir yang sudah banyak dipengatuhi oleh adanya perkembangan teknologi, misalnya adanya internet, handphone, dan lain sebagainya. Handphone tidak lagi menjadi barang baru bagi masyarakat di desa Nolokerto kecamatan Kaliwungu ini, karena hampir sebagian besar mereka sudah memiliki handphone dan menggunakan handphone sebagai kebutuhan sehariharinya. Walaupun tinggal di desa, masyarakat di desa Nolokerto tidak pernah ketinggalan berita, hal ini karena mereka bisa mengakses segala berita dan berkomunikasi melalui handphone. Handphone yang kita tahu merupakan salah satu alat untuk menggunakan media sosial. Media sosial bisa apa saja, facebook, twitter, instagram dan lain-lain.

Media sosial digunakan sebagai sarana berkomunikasi dan memperluas komunikasi bagi masysrakat dan membuat interaksi sosial masyarakat semakin luas. Keberadaan internet yang merupakan saranan untuk masuk dalam media sosial sangat dibutuhkan masysrakat. Selain itu media sosial juga digunakan untuk mencari informasi apa saja yang dibutuhkan oleh masyarakat, sehingga masysrakat akan lebih cepat menerima informasi tanpa harus menunggu lama. Dalam hitungan detik masalah-masalah yang baru terjadi bisa langsung dinikmati melalui media sosial. Kemudahan yang didapatkan dengan berkomunikasi lewat media sosial membuat banyak keuntungan terlepas dari beberapa kerugian dari penggunaan media sosial.

\section{b. Karakter Kebangsaan}

Berbicara tentang karakter kebangsaan tidak terlepas dari karakter bangsa Indonesia yang harus disesuaikan nilai-nilai Pancasila. Jauh sebelum Indonesia merdeka nilai-nilai Pancasila sudah tertanam dalam kehidupan bangsa Indonesia., hal ini tercermin dalam perilaku Bangsa Indonesia yaitu

1. Mengakui adanya causa prima atau penyebab yang utama. Jauh sebelum manusia mengerti tentang Tuhan manusia sudah mulai mencari-mencari yang menjadikan alam semesta dan manusia serta seluruh makhluk yang ada di bumi. Maka akhirnya mereka mencari ke bendabenda berkekuatan gaib dan roh-roh nenek moyang. Hal inilah yang akhirnya menandai adanya kepercayaan animisme dan dinamisme.

2. Kekeluargaan, rasa ini muncul dan sudah ada sejak jaman nenek moyang bangsa Indonesia.

3. Gotong royong, nenek moyang bangsa Indonesia melakukan kegotongroyongan dalam melaksanaan aktifitas sehari-hari misalnya membuka ladang, bercocok tanam dan lain sebagainya

4. Musyawarah mufakat, nilai ini juga sudah dilakukan jaman prasejarah sampe sekarang,

5. Toleransi tenggang rasa dan tepo sliro, adalah sikap saling menghargai dalam kehidupan bangsa Indonesia sejak dulu. ( Kaelan, 2014; 23)

Buki-bukti tersebut menunjukan bahwa karakter atau sifat perilaku bangsa Indonesia sebenarnya sejak dulu sudah mencerminkan nilai-nilai Pancasila. Artinya karakter kebangsaan sudah terpatri dalam kehidupan bangsa Indonesia jauh sebelum Indonesia merdeka. Hal ini seharusnya bisa lebih memperkuat 
karakter kebangsaan yang ada dalam masyarakat Indonesia umumnya, karena sebenarnya masyarakat Indonesia di dalam hatinya sudah mewarisi nilai-nilai karakter kebangsaan sejak dulu. Sebenarnya upaya penguatan karakter kebangsaan selalu diusahakan oleh pemerintah dengan berbagai cara, baik melalui pendidikan fomal maupun informal. Membangun karakter kebangsaaan dirasa sangat penting untuk mewujudkan Indonesia yang lebih baik.

Membangun karakter bangsa menurut Singa Tambunan perlu dilakukan untuk membina dan mengembangkan karakter kebangsaan Indonesia agar supaya mampu mewujudkan nilai -nilai pancasila yang meliputi berkeTuhanan Yang Maha Esa, ber kemanusiaan yang adil dan beradab, berpersatuan Indonesia, berkerakyatan yang dipimpin oleh hikmat kebijaksaaan dalam permusyawaratan /perwakilan serta berkeadilan sosial bagi seluruh rakyat Indonesia. Jika hal tersebut sudah dilaksanakan secara benar makan karakter kebangsaan seluruh masyarakat Indonesia akan terjaga dengan baik hal tersebut tercermin dari perilaku sikap yang sesuai dengan nilai-nilai Pancasila. Maka dari itu, untuk menjaga karakter kebangsaan yang sudah dimiliki bangsa Indinesi sejak dulu maka diupayakan supaya karakter kebangsaan ditanamkan sejak usia dini agar dapat membentuk pribadi yang baik dalam menunjang kehidupan berbangsa dan bernegara serta bermasyarakat.

Perlunya penguatan karakter bangsa agar supaya bisa menciptakan lingkungan yang sesuai dengan jati diri bangsa Indonesia. Era globalisasi membuat banyak kemudahan bagi setiap oranguntuk mendapatkan informasi melalui internet dan gadged. . Hal ini menyebabkan seringnya informasi tersebut tidak disaring dan ditelan mentah-mentah tanpa melihat penting atau tidak, benar atau tidak, bahkan kadang-kadang masyarakat meniru apa yang dilihat. Karakter kebangsaan harus selalu didasarkan nilai-nilai Pancasila, agar di era globalisasi seperti sekarang ini, kepribadian Indonesia tidak terkikis oleh teknologi.

c. Penguatan Karakter Kebangsaan Melalui Media Sosial pada masyarakat di desa Nolokerto Kecamatan Kaliwungu

Masyarakat di desa Nolokerto kecamatan Kaliwungu sesui data yang peneliti peroleh berjumlah 8.228 yang terdiri dari berbagai tingkat pendidikan. Paling banyak masyarakat di desa Nolokerto belum bersekolah atau tidak bersekolah. Melihat hal tersebut akan sangat berpengaruh terhadap sikap perilaku masyarakat..

Tabel ; Penduduk Berdasarkan Tingkat Pendidikan

\begin{tabular}{|c|l|c|r|r|}
\hline NO & \multicolumn{1}{|c|}{ Tingkatan } & Laki-laki & Perempuan & \multicolumn{1}{c|}{ Jumlah } \\
\hline & Tidak atau Belum Sekolah & 1.208 & 1.258 & 2466 \\
\hline & Belum Tamat SD & 287 & 274 & 561 \\
\hline & Tamat SD/MI Sederajat & 1.090 & 1.194 & 2.284 \\
\hline & Tamat SMP/MTs Sederajat & 701 & 709 & 1.410 \\
\hline
\end{tabular}




\begin{tabular}{|l|l|c|c|c|}
\hline Tamat SMA/MA Sederajat & 874 & 629 & 1.503 \\
\hline Diploma I/II & 3 & 1 & 4 \\
\hline $\begin{array}{l}\text { Akademi/Diploma } \\
\text { III/Sarjana Muda }\end{array}$ & 37 & 37 & 74 \\
\hline
\end{tabular}

Sumber : Data monografi desa Nolokerto

Berdasarkan tabel diatas menunjukan bahwa masyarakat di Desa Nolokerto lebih di dominasi anak yang putus sekolah dengan berbagai sebabnya. Walau demikian pengetahuan mereka tentang internet, gadged dan lain sebagainya cukup memadai, hal ini terlihat dari banyaknya anak-anak SD atau yang hanya tamat SD sudah bermain gadged. Mereka ketika ditanya tentang media sosial facebook, instagram, wa, handphone, sangat lancar menjawab, hal ini menandakan bahwa walaupun mereka putus sekolah tetapi masalah teknologi gadged bisa memahami.

Karena kebanyakn di rumah dan jika tidak diarahkan ke kegiatan yang positif tentu akan berakibat buruk dalam pergaulan atau sikap perilaku masyarakat. Sebagai masyarakat yang agamis, di desa Nolokerto ada beberapa mushola untuk menjalankan ibadah dan untuk kegiatan keagamaan yang dilakukan anak-anak, remaja dan juga orang tua. Masyarakat desa Nolokerto merupakan masyarakat yang menjunung tinggi adat budaya yang berlaku di masyarakat. Karakter yang mencerminkan nilai-nilai Pancasila sudah terlihat pada masysrakat Nolokerto. Hal ini dibuktikan dengan sering diadakan pertemuan di lingkup masyarakat RT RW sehingga membuat masyarakat menjadi dekat dan mengenal satu sama lain. Pertemuan yang berbagai macam bidang kegiatan antra lain, kegamaan, kemasyarakatan misalanya arisan, posyandu, gotong royong dan lain sebagainya.

Sebenarnya jika melihat seperti itu, sudah bisa dilihat karakter dari masyarakat desa Nolokerto. Mereka sebagian besar masih menjunjung tinggi nilai-nilai luhur budaya bangsa dilihat dari perilaku sifat kesehariannya dalam pergaulan di sekitarnya. Walaupun demikian, masyarakat juga perlu mewasdai adanya kemajuan teknologi yang begitu besar sydah masuk dalam kehidupan masyarakat Nolokerto. Era globalisasi membuat masyarakat mau tidak mau harus bisa mengikuti perkembangan teknologi. Media sosial yang sudah sangat merajai di dalam kehidupan harus bisa kita terima secara bijak, demikian juga di masyarakat desa Nolokerto. Bagi mereka media sosial tidaklah asing dalam kesehariannya. Hal inilah yang menyebabkan perlu diadakannya sosialisasi penggunaan media sosial secara bijak untuk memperkuat karakter kebangsaan yang sudah ada di dalam kehidupan masysrakat desa Nolokerto.

Karakter yang sudah dimiliki oleh masyarakat desa Nolokerto yang merupakan karakter yang sudah terpelihara sejak lama, perlu dipertahankan. Karakter dan perilaku masysrakat desa Nolokerto merupakan pencerminan dari nilai-nilai budaya bangsa dan mencerminkan nilai-nilai Pancasila. Nilai-nilai keagamaan, kemasyarakatan, kekeluargaan, gotong royong dan rasa sosial di masyarakat desa Nolokerto merupakan karakter yang harus ada walaupun pengaruh globalisasi semakin kuat. Globalisasi tidak mampu merubah sifat dan karakter yang sudah mendarah daging dalam kehidupan masyarakat. Masuknya teknologi gadged dan sejenisnya membuka banyak peluang untuk mengetahui segala macam informasi yang bisa didapat 
dengan mudah. Walaupun demikian nilai-nilai lokal dalam masyarakat tidak bisa tergusur karena kemajuan teknologi.

Media sosial justru akan membantu masyarakat desa Nolokerto untuk bisa mengetahui segala macam informasi yang dibutuhkan. Dengan informasi yang dipilih dengan bijak akan membuat masyarakat menjadi lebih pandai menyikapi segala hal yang terjadi dalam kehidupan. Melalui sosial media, masysrakat bisa saling berinteraksi dengan sesamanya, juga dapat saling bertukar informasi dari yang sebelumnya tidak tahu menjadi tahu berita-berita terbaru. Melalui media sosial karakter masysrakat bisa menjadi lebih kuat untuk lebih mencintai bangsanya sendiri. Melalui komunikasi dengan media sosial bisa memilih mana informasi yang benar dan tidak, sehingga masyakarat menjadi lebih bijak.

Mensosialisasikan kegunakan sosial media kepada masyarakat, sehingga masyarakat lebih tahu dan lebih bijaksana dalam menggunakan media sosial. Menjelaskan akibat jika kita tidak bijak menggunakan dengan perkataan sikap perilaku yang tidak sesuai dengan karakter dan budaya bangsa. Bukan orang lain yang akan malu akan tetapi diri sendiri yang malu, karena media sosial dapat dibaca dan diketahui banyak orang. Facebook, twitter, instagram dan sejenisnya, membuat kita mendapatkan banyak teman baru, disamping fungsi lainnya antara lain bisa mempromosikan produk yang kita jual. Masyarakat juga bisa mengembangkan segala macam bakat yang dimiliki dengan melalui media sosial. Sehingga masyarakat bisa lebih kreatif dan inovatif dalam mengembangkan bakat dan hobynya untuk lebih mensejahterakan diri dan keluarganya. Dengan demikian melalui media sosial masyarakat juga bisa meningkatkan perekonomian keluarga.

\section{Kesimpulan}

Media sosial memiliki dampak positif dan negatif, dan untuk meminimalisir dampak negatif semua elemen harus bisa saling bekerjasama untuk mewujudkan penggunaan media sosial yang bijak. Dampak positif media sosial, masyarakat desa Nolokerto lebih kreatif dan inovatif dalam mengembangkan bakat dan hobynya dengan menggunakan media sosial. Komunikasi melalui facebook, twitter, instagram membuat masyarakat lebih kenal dan dekat satu sama lain. Saling ber interaksi melalui media sosial dengan bertukar pikiran yang serius atau sekedar bercandaan membuat masyarakat lebih menguatkan kepribadian yang sebenarnya. Terlebih yang lebih penting masyarakat lebih pandai dan memiliki pengetahuan yang sebelumnya tidak mereka dapatkan.

Selain dampak positif, terdapat dampak negatif dengan penggunaan media sosial. Masyarakat cenderung kurang bersosialisasi dan berinteraksi secara langsung. Disamping juga dikuatirkan adanya penyalahgunaan media sosial, sehingga bukan menimbulkan keuntungan tapi justru kerugian dalam masyarakat. Maka di masyarakat desa Nolokerto perlu ditekankan kembali penggunaan media sosial secara benar. 


\section{Daftar pustaka}

Antony, Mayfield. 2008. What is Social Media?. Universitas Kristen Maranata: Jakarta

Badan Pengembangan dan Pembinaan Bahasa. 2016. Kamus Besar Bahasa Indonesia Edisi Kelima.

Kaelan, 2014. Pendidikan pancasila. Paradigma: Yogyakarta

Kemendiknas RI. 2010. Disain Induk Pendidikan Karakter. Jakarta

Kementrian Pendidikan dan Kebudayaan Republik Indonesia.

Sanjaya R; Wibhowo C; Adi A. P. 2010. Parenting untuk Pornografi di Internet. Gramedia: Jakarta

Singa Tambunan, 2014. Membangun Karakter Bangsa berdasarkan Nilai-nilai Pancasila. Kompasiana

Udin Saripudin. 2012. Pendidikan Karakter Bangsa. Program Pasca Sarjana: Bandung 